\title{
Novel $\mathrm{CeO}_{2}$-based Screen-Printed Potentiometric Electrodes for pH monitoring
}

\author{
S. Betelu ${ }^{1 *}$, K. Polychronopoulou ${ }^{2}$, C. Rebholz ${ }^{2}$, I. Ignatiadis ${ }^{1}$ \\ ${ }^{1}$ BRGM, Environment and Processes Division, 45060 Orléans Cedex 2, France \\ ${ }^{2}$ Mechanical and Manufacturing Engineering Department, University of Cyprus, 1678 Nicosia, Cyprus
}

\begin{abstract}
\end{abstract}
Nuclear waste repositories are being installed in deep excavated rock formations in some places in Europe to isolate and store radioactive waste. In France, the Callovo-Oxfordian formation $(\mathrm{COx})$ is a possible candidate for nuclear waste storage. This work investigates the applicability of $\mathrm{CeO}_{2}$-based oxides $\left(\mathrm{CeO}_{2}, \mathrm{Ce}_{0.8} \mathrm{Sm}_{0.2} \mathrm{O}_{2}\right.$ and $\left.\mathrm{Ce}_{0.8} \mathrm{Zr}_{0.2} \mathrm{O}_{2}\right)$ for monitoring the $\mathrm{pH}$ of the COx pore water. The study is limited to the $\mathrm{pH}$ range between 5.5 and 13.2, which includes the $\mathrm{pH}$ values that have been encountered or are anticipated in the $\mathrm{COx}$ formation during its evolution as radioactive waste repository due mainly to alkalinisation, an increase in salinity, a decrease in redox potential. Screen-printing was done to assemble electrodes and rapidly generate data sets. The electrochemical behavior of $\mathrm{CeO}_{2}$-based screen-printed electrodes $\left(\mathrm{CeO}_{2}\right.$-based SPEs) was determined by cyclic voltammetry and electrochemical impedance spectroscopy. The use of the electrodes for $\mathrm{pH}$ sensing was then evaluated by potentiometric measurements. The feasibility of measuring $\mathrm{pH}$ with $\mathrm{CeO}_{2}$-based SPEs was first tested in $\mathrm{NH}_{4} \mathrm{Cl} / \mathrm{NH}_{3}$ buffer solutions, leading to electrode calibration over the widest range of $\mathrm{pH}$, from around neutral to basic $\mathrm{pH}$. Experiments were then conducted in $\mathrm{NaHCO}_{3} / \mathrm{Na}_{2} \mathrm{CO}_{3}$ buffer samples similar to conditions prevailing in the $\mathrm{COx}$ formation. $\mathrm{Ce}_{0.8} \mathrm{Zr}_{0.2} \mathrm{O}_{2}$ SPEs exhibit a near-Nernstian behavior (sensitivity $-(51 \pm 2) \mathrm{mV} / \mathrm{pH}$ ) in the $\mathrm{pH}$ range 5.5-13.2 at $25{ }^{\circ} \mathrm{C}$. Electrode response was slightly affected by the direction of the $\mathrm{pH}$ change. Electrode reliability was clearly demonstrated for $\mathrm{pH}$ monitoring. Probes based on the same components, but more durably designed, could be considered for $\mathrm{pH}$ measurements in radioactive waste repositories.

Keywords: pH sensing, cerium-based oxides, mass modified screen-printed electrodes, monitoring

* Corresponding author. Tel.:+33238643268; fax: +33238643062; e-mail address: s.betelu@brgm.fr 


\section{Introduction}

Radioactive waste repositories are being installed in deep excavated rock formations in some places in Europe to isolate and store radioactive waste. It is therefore necessary to measure, in situ, the health of the structure throughout its life. The near-field rock can be monitored and knowledge of any geochemical transformations can be acquired using sensors, thus enabling the sustainable management of long-term safety, reversibility and retrievability [1]. The most significant chemical parameters are $\mathrm{pH}$, conductivity and redox potential.

$\mathrm{pH}$ is one of the most important parameters characterizing samples [2]. Extensive efforts have been devoted to developing highly sensitive analytical procedures for measuring $\mathrm{pH}$. There is, however, an increasing need for sensing probes for continuous measurements on site and their development represents a serious challenge in terms of accuracy, repeatability and particularly robustness.

Based on reversible interfacial redox processes that involve protons [3, 4], metal oxide potentiometric electrodes have been regarded as the most promising technologies for $\mathrm{pH}$ measurements [3-19] due to their intrinsic mechanical stability with regard to temperature, pressure and aggressive environments [3, 20]. Furthermore, oxide-based electrodes have the advantage of being easily miniaturized $[3,20,21]$.

Niedrach (1980 a,b) was the first to report on the application of zirconium oxide (zirconia, $\mathrm{ZrO}_{2}$ ) membrane-type potentiometric sensors for $\mathrm{pH}$ measurements [22, 23]. However, this membrane electrode exhibited only a near-Nernstian-pH response at high temperatures [24, 25] and, because of their high impedance [26], $\mathrm{pH}$ sensors with zirconia membranes were reported to exhibit sluggish and sub-theoretical responses at temperatures below $150{ }^{\circ} \mathrm{C}$ [27]. The study of new zirconia-based materials with higher ionic conductivity should extend the operating temperature limits. 
Compared to zirconia, $\mathrm{CeO}_{2}$ (ceria) has a considerably higher oxide-ion conductivity [28, 29]. Moreover, because of its particular and unique properties, cerium, a Rare Earth Element (REE), might be used for robust, long-term sensors. Indeed, cerium's Eh-pH diagram differs from those of other REEs [30]. Cerium has a Ce(IV) valence in addition to $\mathrm{Ce}(\mathrm{III})$ and large pe-pH domain for the $\mathrm{Ce}(\mathrm{IV})$ species. $\mathrm{CeO}_{2}$ dominates much of the water stability field. This field also covers much of the $\mathrm{Ce}^{3+}$ field as well. Furthermore, it is a non-stoichiometric n-type semiconductor with oxygen vacancies as predominant ionic defects, and the oxygen-vacancy concentration as well as oxide-ion conductivity in $\mathrm{CeO}_{2}$ can be increased by substitution. Balazs and Glass (1995) showed that, of all the ceria solid electrolytes, $\mathrm{Ce}_{0.8} \mathrm{Sm}_{0.2} \mathrm{O}_{2}$ had the highest oxide ion conductivity [28]. Samarium-substituted ceria ceramic membrane-type $\mathrm{pH}$ sensors have been reported to exhibit a Nernstian slope in buffer solutions at $75^{\circ} \mathrm{C}[31,32]$. It would, therefore, be of great interest to use binary compositions, especially Zr-substituted ceria oxides, to improve the sensitivity of sensors for $\mathrm{pH}$ monitoring at lower temperatures.

In the study reported here, the possible use of a $\mathrm{CeO}_{2}$-based electrode $\left(\mathrm{CeO}_{2^{-}}, \mathrm{Ce}_{0.8} \mathrm{Sm}_{0.2} \mathrm{O}_{2}-\right.$ and $\mathrm{Ce}_{0.8} \mathrm{Zr}_{0.2} \mathrm{O}_{2}$-based screen-printed electrodes SPEs) was investigated for continuous $\mathrm{pH}$ measurements. An Sm-substituted ceria oxide composition was synthesized as described by Balazs and Glass (1995) [28] and was also studied for Zr-substituted ceria oxide. Moreover, these Ce-rich compositions preserved the cubic fluorite lattice of $\mathrm{CeO}_{2}$, which has beneficiary properties such as high Oxygen Storage Capacity (OSC) [33]. The screen-printing process was chosen as the most appropriate technology for assembling reproducible electrodes [34, 35] and rapidly generating data sets. This technology has been used to develop electrodes based on $\mathrm{PdO}, \mathrm{TiO}_{2}, \mathrm{PtO}_{2}[14], \mathrm{RuO}_{2}[14,36]$ and $\mathrm{CoO}_{2}$ [37]. Of these, the $\mathrm{RuO}_{2}$ - and $\mathrm{CoO}_{2-}$ based electrodes were reported to be the most sensitive. Nevertheless, carbon-based mass-modified $\mathrm{RuO}_{2}$ screen-printed electrodes only exhibited a near-Nernstian behavior $-(51.2 \pm 0.1)$ in the non-alkaline $\mathrm{pH}$ range (2-7) [14]. In comparison, ruthenium dioxide-glass 
composite demonstrated a Nernstian behavior between $\mathrm{pH} 2$ and 12 and therefore might be used as a pH sensor [36]. However, these electrodes only exhibited long-term mechanical stability between pH 5 and 9, probably due to mechanical strain owing to pH-dependent expansion and contraction of a hydrated phase within the composite. Concerning the $\mathrm{CoO}_{2^{-}}$ based electrodes, the optimization of both the nature and the amount of the incorporated salt led to an electrode exhibiting a Nernstian behavior in the $\mathrm{pH}$ range 2-12. Moreover, these electrodes worked for 5 days at $\mathrm{pH} 4$ with a relative standard deviation of about $10 \%$. However, their robustness for alkaline $\mathrm{pH}$ has not been verified.

In this study, $\mathrm{CeO}_{2}$-based $\mathrm{SPE}$ performance levels, reliability and robustness for $\mathrm{pH}$ determination were investigated by potentiometric measurements at $25^{\circ} \mathrm{C}$. Only the $\mathrm{pH}$ range that includes previously encountered or anticipated $\mathrm{pH}$ values in the Callovo-Oxfordian formation (Cox) during its evolution as a radioactive waste repository ( $\mathrm{pH} 6$ to 13) were studied. The feasibility of the $\mathrm{pH}$ electrodes was first tested in $\mathrm{NH}_{4} \mathrm{Cl} / \mathrm{NH}_{3}$ buffer solutions, which led to electrode calibration over the widest range of $\mathrm{pH}$, from around neutral to basic pH. Experiments were also conducted in $\mathrm{NaHCO}_{3} / \mathrm{Na}_{2} \mathrm{CO}_{3}$ buffer samples similar to conditions prevailing in the COx formation [38].

\section{Materials and methods}

2.1 Synthesis of $\mathrm{CeO}_{2}$-based powders

Cerium oxide $\left(\mathrm{CeO}_{2}, \mathrm{Ce}_{0.8} \mathrm{Sm}_{0.2} \mathrm{O}_{2}\right.$ and $\left.\mathrm{Ce}_{0.8} \mathrm{Zr}_{0.2} \mathrm{O}_{2}\right)$ powders were synthesized using procedures similar to those previously described [39]. 


\subsection{Sensor assembly}

\subsubsection{Ink preparation}

$\mathrm{CeO}_{2}$-based inks were prepared by adding $\mathrm{CeO}_{2}$-based powders $\left(\mathrm{CeO}_{2} 50 \%\right.$ (w/w)) directly to a commercial carbon-based ink (Electrodag PF 407A from Acheson, a mixture of carbon black (particle size lower than $1 \mu \mathrm{m}$ ) and graphite carbon (particle size ranging from $8.5 \mu \mathrm{m}$ (255 $10^{-6}$ inch) to $18 \mu \mathrm{m}\left(54010^{-6}\right.$ inch). The mixture was stirred by hand for 5 min prior to the printing process.

\subsubsection{Screen-printing}

A manual screen-printer (from Circuit Imprimé Français, France) was used to make the sensors. An array of six electrodes was printed on $1 \mathrm{~mm}$-thick polystyrene plates (Sericol) by forcing the conductive ink through the mesh of a polyester screen stencil $\left(77\right.$ threads $\mathrm{cm}^{-1}$, Circuit Imprimé Français, France).

After drying ( $1 \mathrm{~h}$ at room temperature) and curing $\left(1 \mathrm{~h}\right.$ in an oven at $\left.60{ }^{\circ} \mathrm{C}\right)$, a layer of insulation (a thin layer of polystyrene dissolved in mesitylen (Fluka Analytical, France), which evaporates slowly, in two days, at room temperature) was spread by hand over the conductive track (20 mm x $1 \mathrm{~mm}$ ), leaving a $9.6-\mathrm{mm}^{2}$ working disk area and a $25-\mathrm{mm}^{2}$ square tip for electrical contact (Fig. 1). In accordance with Cagnini et al. (1995) [40] and Koncki et al. (1997) [14], the typical thickness of the film was around $20 \mu \mathrm{m}$. The screen-printing process enabled the assembly of small batches of approximately 20 electrodes.

Unmodified carbon-based SPEs (C SPEs) were also prepared by screen-printing with the commercial ink without any modification in order to compare the properties of $\mathrm{CeO}_{2}$-based SPEs to carbon electrodes (reference samples). 


\subsection{Measurements}

\subsubsection{Apparatus}

All the potentials were measured with respect to the saturated calomel electrode (SCE), which consisted of a commercial SCE protected with a $\mathrm{KCl} 3 \mathrm{~mol} \mathrm{~L}^{-1}$ junction. The junction potential is less than $1 \mathrm{mV}$ at $25^{\circ} \mathrm{C}$. The difference in voltage was measured with a millivoltmeter between protected and unprotected SCE, both immersed in $\mathrm{NaCl} 0.1 \mathrm{~mol} \mathrm{~L}^{-1}$. All potential values herein are expressed in Volt (V) with respect to the Normal Hydrogen Electrode (NHE) scale by adding $245 \mathrm{mV}$.

DC electrochemical techniques were used on thermostated samples using a potentiostatgalvanostat (Princeton Applied Research, Tennessee, USA) PAR model-2273, interfaced to a PC system with PAR's PowerSuite v.2.58 software. A platinum wire was used as an auxiliary electrode. The working solution volume was $10 \mathrm{~mL}$.

Cyclic voltammetry $(\mathrm{CV})$ measurements were done at $50 \mathrm{mV} \mathrm{s}^{-1}$ between $-0.8 \mathrm{~V} / \mathrm{NHE}$ and 1.7V/NHE. Electrochemical Impedance Spectroscopy (EIS) measurements were done over a frequency range of $10 \mu \mathrm{Hz}$ to $1 \mathrm{MHz}$ using perturbation signals with an amplitude of $5 \mathrm{mV}$. The computer-assisted evaluation of the impedance spectra was done with the PAR-2273 impedance measurement system using an integrated data-acquisition and analysis system and the ZSimWin v.3.21 software (Echem Software, Bruno Yeum, Ann Arbor, Michigan, USA).

Potentiometric measurements were recorded continuously in thermostated samples with a digital multimeter and data acquisition system (Keithley instruments, model 2700, Cleveland, USA). The sample volume was $100 \mathrm{~mL}$. $\mathrm{CeO}_{2}$-based SPEs pH-sensing characteristics were evaluated by measuring their open-circuit potential (OCP) versus SCE. The $\mathrm{pH}$ values of all samples and buffer solutions were monitored with a commercial glass electrode that was calibrated daily using commercial standard buffer solutions. 


\subsubsection{Solutions}

All experiments were done at a constant temperature $\left(\mathrm{T}=25.00 \pm 0.04{ }^{\circ} \mathrm{C}\right)$ under continuous stirring (about $200 \mathrm{rpm}$ ) in $\mathrm{NaCl} 0.1 \mathrm{~mol} \mathrm{~L}{ }^{-1}, \mathrm{NH}_{4} \mathrm{Cl} / \mathrm{NH}_{3}$ or $\mathrm{NaHCO}_{3} / \mathrm{Na}_{2} \mathrm{CO}_{3}$ buffer solutions. The preparation of $1 \mathrm{~L}$ of the buffer solutions is summarized in table 1 . PHREEQC ${ }^{\circledR}$ geochemical code was used to determine the total equivalent activity of the different ions with the appropriate associated thermodynamic database (THERMODEM ${ }^{\circledR}$ thermodynamic database generated by BRGM). It is worth noting that no Pitzer database was available at BRGM. The thermodynamic calculations were not investigated for supporting electrolyte which ionic strength was higher than $0.1 \mathrm{~mol} \mathrm{~L}^{-1}$.

\section{Results and discussion}

3.1 SPE assembly and electrochemical characterization

\subsubsection{Electrode assembly}

The screen-printing process was selected as the most appropriate technology for making reproducible electrodes $[34,35]$ and rapidly generating data sets. It involves transferring a thin layer of a conductive ink onto a rigid substrate through the mesh of a screen pattern [41]. Polyester screens are usually used for printing, with patterns designed in accordance with the analytical purpose in mind [42]. The ink is made up of (i) the active material, which ensures conductivity: a powder of conductive particles (maximal particle size: $10 \mu \mathrm{m}$ ), (ii) a binder, which ensures cohesion by linking the active material and the substrate, and (iii) an organic solvent, which gives the right rheological properties. The solvent is removed by drying and/or heating. The composition of the ink determines the selectivity as well as the sensitivity of the sensor. The direct addition of $\mathrm{CeO}_{2}$-based oxides to the commercial carbon-based ink prior to the printing process was tested in order to simplify electrode assembly. Various proportions of $\mathrm{CeO}_{2}$-based powders (up to $80 \%(\mathrm{w} / \mathrm{w})$ ) were added to the conductive ink, the aim being to 
add as much as possible. The carbon-based ink ensured both conductivity and cohesion. $50 \%$ (w/w) was found to be the highest amount of $\mathrm{CeO}_{2}$ possible to produce (i) ink fluid enough to be spread as a single layer (thickness $\cong 20 \mu \mathrm{m}[14,40]$ ) on the stencil and (ii) a matrix that ensured consistency and enabled the adhesion of electrodes to the flexible support.

The influence of the composition of the $\mathrm{CeO}_{2}$-based ink on the electrochemical characteristics (i.e. potential range, capacitive current, conductive properties and electrode/solution interface characterization) of each type of $\mathrm{CeO}_{2}$-based $\mathrm{SPE}$ was determined by $\mathrm{CV}$ or EIS measurements. The results were compared to those obtained with unmodified C SPEs. All experiments were done in $10 \mathrm{~mL}$ of $\mathrm{NaCl} 0.1 \mathrm{~mol} \mathrm{~L}^{-1}$ solution. For each type of SPE, tests were done with five different electrodes.

\subsubsection{Potential range}

The potential range, which is the window of potential values in which the reduction or oxidation of species can be observed, determines the electrode polarization domain [43]. The reduction of protons (towards $\mathrm{H}_{2}$ ) determines the polarization domain towards the negative potentials, whereas oxidation of (i) the water (towards $\mathrm{O}_{2}$ ) or (ii) the electrode material constitutes the positive limit.

SPE potential ranges were determined from the voltammograms obtained by CV (Fig. 2).

$\mathrm{CeO}_{2}$-based SPEs have a potential window as wide as those of unmodified carbon-based SPEs, ranging from $-0.1 \mathrm{~V} / \mathrm{NHE}$ to $+1.4 \mathrm{~V} / \mathrm{NHE}$. This shows that these electrodes behave as almost inert materials working over a wide potential range at a given $\mathrm{pH}$. 


\subsubsection{Capacitive current}

Capacitive current values were obtained for $\mathrm{E}=0.7 \mathrm{~V} / \mathrm{NHE}$ from the voltammograms recorded by $\mathrm{CV}$ (Table 2). In agreement with the literature, C SPEs have a very low capacitive current $[42,44]$. A similar result was obtained for $\mathrm{CeO}_{2} \mathrm{SPEs}$, due to the high exchange current density of $\mathrm{CeO}_{2}[28]$.

Cerium substitution by samarium or zirconium led to an increase in the charging current by factors of 6.5 and 12.0 for $\mathrm{Ce}_{0.8} \mathrm{Sm}_{0.2} \mathrm{O}_{2}$ SPEs and $\mathrm{Ce}_{0.8} \mathrm{Zr}_{0.2} \mathrm{O}_{2}$ SPEs, respectively. This might be due to the fact that oxygen vacancies are the main charge carriers for $\mathrm{Ce}_{0.8} \mathrm{Sm}_{0.2} \mathrm{O}_{2}$ SPEs and $\mathrm{Ce}_{0.8} \mathrm{Zr}_{0.2} \mathrm{O}_{2}$ SPEs. The difference between $\mathrm{Ce}_{0.8} \mathrm{Sm}_{0.2} \mathrm{O}_{2}$ and $\mathrm{Ce}_{0.8} \mathrm{Zr}_{0.2} \mathrm{O}_{2}$ can be assigned to the difference in microstructure. This can be expressed in terms of the different extent of distortion due to expected different solid solubility, as implied by the different ionic radii of $\mathrm{Sm}^{3+}(1.04 \AA), \mathrm{Ce}^{4+}(1.01 \AA)$ and $\mathrm{Zr}^{4+}(0.72 \AA)$. However, the capacitive current observed was of the same order of magnitude as that of the solid electrodes [44], which meant that high-input impedance equipment was not needed for subsequent measurements. These results suggest a greater sensitivity of the newly assembled SPEs compared to those described in the literature $[23-25,27,45]$, which work at temperatures below $150{ }^{\circ} \mathrm{C}$.

\subsubsection{Conductive properties}

The study of the conductive properties of each type of SPE involved comparing the cyclic voltammograms obtained with the SPEs and the electrochemical behavior of $\mathrm{Fe}(\mathrm{III}) / \mathrm{Fe}(\mathrm{II})$ using the ferrocenylmethyl-trimethyl-ammonium hexafluorophosphate probe [46].

The difference $|\Delta \mathrm{E}|$ (Table 3) between the oxidation and reduction peaks of the $\mathrm{Fe}(\mathrm{III}) / \mathrm{Fe}(\mathrm{II})$ couple made it possible to estimate the speed of electronic charge transfer of the $\mathrm{CeO}_{2}$-based SPE compared to that of unmodified SPEs. The intensity of the anodic and catholic peaks $\left(i_{p}\right)$ 
made it possible to estimate the reversibility at the electrode of the well-known reversible redox phenomenon.

The cathodic and anodic peak currents are the same and reproducible (relative standard deviation, RSD $<5 \%$ ) for all types of SPEs, which shows the reversibility of the redox phenomenon at the working surfaces. Measured $|\Delta \mathrm{E}|$ values were close to the theoretical values for rapid electron transfer $(56 \mathrm{mV})$ [43], which shows that no decrease in the electron transfer rate is observed when electrodes were modified by $\mathrm{CeO}_{2}$-based oxides.

\subsubsection{Electrochemical impedance measurements and their interpretation}

Impedance measurements were performed to investigate the elementary phenomena encountered at the electrolyte/electrode interfaces of $\mathrm{CeO}_{2}$-based SPEs. They were compared to those obtained with C SPEs.

The EIS diagrams obtained (also shown in the Bode mode in figure $3 \mathrm{C}$ ) were analyzed using the ZSimpWin software (version 3.21 by Bruno Yeum, Ann Arbor Michigan, USA). Data processing makes it possible to read the data in terms of an equivalent electric circuit (EEC) obtained with a very close fit. The interpretation of impedance measurements and simulation then led to the determination of an EEC model, representing the behavior of the electrode/solution interface. This involves extracting the parameters from a model starting with impedance data, or in other words, seeking a model for which the impedance matches the measured data.

After modeling, using the EIS data obtained on the four disk-shaped oxide SPEs, two possible EECs are established (Fig. 4). It appears that all of the EIS diagrams can be described by these two EEC for all electrodes (Fig. 4). Both diagrams are the same (each EEC model was well fitted to data). Almost all of the parameters were obtained with an error lower than $5 \%$. On 
the other hand, this implies that only the values of the parameters of the obtained EEC will change when the nature of the electrode changes.

For the different electrodes, the variations under the same experimental conditions result in different parameter values for each component of the exposed EEC (Table 4). The chi-square test $\left(\chi^{2}\right.$ test) was done for each simulation and enabled us to confirm that the results given by the model matched the measured values (reduced values). The electrode surface is about 10 $\mathrm{mm}^{2}$ (or $\left.0.1 \mathrm{~cm}^{2}\right)$.

$\mathrm{R}$ represents dc-resistance (in admittance 1/R), C represents capacitor (in admittance $i \omega C$ ) and $\mathrm{Q}$ is a Constant Phase Element (CPE) or equivalent capacitance and corresponds to a semiinfinite diffusion or an imperfect (leaking) capacitor. Q (in admittance is $Y_{o}(i \omega)^{n}$ ) is characterized by two parameters, $\mathrm{Y}_{\mathrm{o}}$, which is the Warburg (W) element parameter, and $\mathrm{n}$. When $\mathrm{n}=1$, $\mathrm{Q}$ is only a $\mathrm{C}$ (capacitor).

The form of the impedance, in Nyquist mode, is an impedance of an immobile plane electrode immersed in an agitated electrolyte. It is an impedance of semi-infinite diffusion of type Q corresponding to a redox reaction (probably involving $\mathrm{O}_{2}$ ). This type of impedance intervenes in the reactions of the electrode when there is material transport by diffusion in a semi-infinite (in volume) phase.

Except for $R_{e}$, which is the electrolyte resistance (in ohms) and is very low (because of the high conductivity of the $\mathrm{NaCl} 0.1 \mathrm{~mol} \mathrm{~L}^{-1}$ supporting electrolyte), the EIS diagram shows that at least two distinct phenomena occur simultaneously at the electrode/solution interface during measurement.

The limiting process - the one that has the slowest kinetics - corresponds to the low frequencies and is shown by an almost straight line. It seems to be invariable with time and corresponds to the mass transport (diffusion-convection) at the electrode/solution interface (either to the dissolved oxygen required for oxidizing the substrate or to another redox 
phenomenon). The component $\mathrm{Q}$ gives a depressed semicircle and represents the flow variation of ions or molecules and the pure diffusion of these species. As $n$ is near to $1, \mathrm{Q}$ is almost a capacitor.

For the high-frequency (on the left), the loop obtained for all the electrodes is attributed to an elementary process by calculating the order of magnitude of its corresponding capacity $\mathrm{C}$, defined by :

$$
\mathrm{C}_{\mathrm{d}}=1 /\left(2 \pi \omega_{0} \mathrm{R}_{\mathrm{t}}\right)
$$

In this equation, $C_{d}$ is the capacity in $\mu \mathrm{F} . \mathrm{cm}^{-2}, \omega_{0}$ is the maximum frequency in $\mathrm{Hz}, \mathrm{R}_{\mathrm{t}}$ is the corresponding charge transfer resistance in ohms. The order of magnitude of the capacities obtained for all the electrodes is between $0.3\left(\mathrm{Ce}_{0.8} \mathrm{Zr}_{0.2} \mathrm{O}_{2}\right.$ SPEs $)$ and $1.9 \mathrm{nF} . \mathrm{cm}^{-2}\left(\mathrm{CeO}_{2}\right.$ SPEs), indicating very rapid phenomena. These values correspond to the capacities obtained during charge transfer, and the loop is a charge transfer loop. The values of $\mathrm{R}_{\mathrm{t}}$ with each electrode show that $R_{t}$ increases enormously when $\mathrm{Sm}$ and $\mathrm{Zr}$ are added to the $\mathrm{CeO}_{2}$-based oxide, which shows that oxygen vacant sites are the charge carriers regulating these phenomena. $\mathrm{Ce}_{0.8} \mathrm{Zr}_{0.2} \mathrm{O}_{2}$ oxide has the lowest $\mathrm{C}_{\mathrm{d}}\left(0.3 \mathrm{nF} . \mathrm{cm}^{2}\right)$ and the highest $\mathrm{R}_{\mathrm{t}}(19140 \mathrm{ohm})$, whereas $\mathrm{CeO}_{2}$ oxide has the highest $\mathrm{C}\left(1.9 \mathrm{nF} . \mathrm{cm}^{2}\right)$ and the lowest $\mathrm{R}_{\mathrm{t}}(1585 \mathrm{ohm})$. These values are similar to those obtained by $\mathrm{CV}$ capacitive currents for theses oxides. Capacitive current for $\mathrm{CeO}_{2}$ is low $(40 \mu \mathrm{A})$, whereas it is very high for $\mathrm{Ce}_{0.8} \mathrm{Zr}_{0.2} \mathrm{O}_{2}(470 \mu \mathrm{A})$, which could be attributed to the increased number of oxygen vacancies in the case of the latter.

The system identified by the impedances is relatively simple and involves mainly a charge transfer reaction. The transfer resistances obtained for the oxide SPEs are in very good agreement with the conductivities through the crystalline grains and the previously obtained results (see II 3.1.3). As opposed to the results of Inda et al., (1996) [27], no grain boundary impedance was observed, probably due to the thinness of the SPEs ). This suggests that $\mathrm{Ce}_{0.8} \mathrm{Zr}_{0.2} \mathrm{O}_{2}$ SPEs are of interest for $\mathrm{pH}$ sensing at $25^{\circ} \mathrm{C}$. 
The results demonstrate the possible use of $\mathrm{CeO}_{2}$-based SPEs as electrochemical sensors and suggest higher sensitivity than with the ceria-, samaria- or zirconia- based electrodes described in the literature [23-25, 27, 45]. Their properties were therefore investigated for $\mathrm{pH}$ potentiometric measurements.

\subsection{Analytical performance and robustness of $\mathrm{CeO}_{2}$-based SPE $\mathrm{pH}$ sensors}

The performance, reliability and robustness of $\mathrm{CeO}_{2}$-based SPEs for $\mathrm{pH}$ determination were studied using potentiometric measurements at $25^{\circ} \mathrm{C}$ (the ambient temperature in the $\mathrm{COx}$ formation). Only $\mathrm{pH}$ values similar to those that are anticipated in the COx formation when used as a radioactive waste repository were studied. Investigations were first done in $\mathrm{NH}_{4} \mathrm{Cl} / \mathrm{NH}_{3}$ buffer solutions, after which the electrodes were calibrated for the widest $\mathrm{pH}$ range, from around neutral to basic $\mathrm{pH}$. A carbonate/hydrogenocarbonate buffer system was then used since carbonate system equilibria constrain the $\mathrm{pH}$ of the clay rock's pore-water $[38]$.

\subsubsection{Feasibility study}

The feasibility of measuring $\mathrm{pH}$ with $\mathrm{CeO}_{2}$-based- SPEs was first tested in $\mathrm{NH}_{4} \mathrm{Cl} / \mathrm{NH}_{3}$ buffer solutions for a pH ranging from 7.2 to 10.8 (Fig. 5). The results were compared to those of C SPEs in order to determine whether the Ce-based oxides were of interest. Measurements for increasing and decreasing $\mathrm{pH}$ values were taken for 5 minutes, at a rate of one reading every 10 seconds.

The general convergence of the stabilization potential of all immersed SPEs revealed the occurrence of an equilibrium state under the experimental conditions. The $\mathrm{CeO}_{2}$-based electrodes rapidly responded to changes in $\mathrm{pH}(\leq 30 \mathrm{~s})$ with regard to the relative standard 
deviation based on repeatability ( $\mathrm{RSD} \leq 3 \%$ ). Furthermore, the equilibrium state remains unchanged with regard to $\mathrm{pH}$ variations, considering the relative standard deviation based on reproducibility $(\mathrm{RSD} \leq 10 \%)$.

The voltage response of the electrodes to changing $\mathrm{pH}$ of the solution is linear. In aqueous solutions, the potential of $\mathrm{CeO}_{2}$-based SPEs is governed by $\mathrm{pH}$, presumably related to the ionexchange properties of cerium oxide. When $\mathrm{CeO}_{2}$-based SPEs come into contact with the solution, surface hydrolysis may occur and a proton exchange process creates an interfacial potential between the solution and the electrode surface. The difference in measured potential depends on $\mathrm{pH}$ when (i) the solution/oxide interface is reversible with respect to proton exchange and (ii) the oxide/substrate interface is electronically reversible. A single-phase oxygen intercalation in $\mathrm{CeO}_{2}$-based oxides may be envisaged similar to the semiconducting oxide $\mathrm{pH}$ sensing mechanism proposed by Fog and Buck [3]. If we omit the water of hydration, we can assume that the electrode reaction is:

$$
\mathrm{Ce}(\mathrm{Sm} / \mathrm{Zr}) \mathrm{O}_{2}+2 \mathrm{nH}^{+}+2 \mathrm{ne}^{-} \leftrightarrow \mathrm{Ce}(\mathrm{Sm} / \mathrm{Zr}) \mathrm{O}_{2-\mathrm{n}}+\mathrm{n} \mathrm{H}_{2} \mathrm{O}
$$

A plot of the measured open-circuit potential versus the $\mathrm{pH}$ should yield a straight line with a Nernstian slope (e.g. $-59.16 \mathrm{mV} / \mathrm{pH}$ at $25^{\circ} \mathrm{C}$ ) when the activity of oxygen in the substituted cerium oxide is assumed to be a constant. The slopes of the potential-pH curves of the three kinds of $\mathrm{CeO}_{2}$-based SPEs and the C SPEs were studied. No Nerstian behavior was observed for C SPEs in the 7.5 to 11 range. A near-Nernstian behavior was observed for $\mathrm{CeO}_{2}$-based SPEs, demonstrating the feasibility of potentiometric measurements with these kinds of working electrodes for $\mathrm{pH}$ determination in water samples. In accordance with [47-49] who established that proton conductive behavior depends on the oxygen vacancy concentration, the highest sensitivity for $\mathrm{Ce}_{0.8} \mathrm{Zr}_{0.2} \mathrm{O}_{2}$ SPEs can be explained by $\mathrm{Ce}_{0.8} \mathrm{Zr}_{0.2} \mathrm{O}_{2}$ being the highest oxygen vacancies carrier (see II 3.1.4). 
Zirconia membranes have been reported to be ideally suited to $\mathrm{pH}$ measurements at temperatures higher than $150{ }^{\circ} \mathrm{C}[24,25] . \mathrm{Sm}$-substituted ceria ceramic membrane-type $\mathrm{pH}$ sensors have been shown to have a Nernstian slope in buffer solutions at $75^{\circ} \mathrm{C}[31,32]$. It is worth noting that the previously mentioned studies [31, 32] did not mention any unmodified ceria ceramic membrane to demonstrate that $\mathrm{Sm}$ was of interest. For the first time, in this work, $\mathrm{CeO}_{2}$ SPEs, $\mathrm{Ce}_{0.8} \mathrm{Sm}_{0.2} \mathrm{O}_{2}$ SPEs and $\mathrm{Ce}_{0.8} \mathrm{Zr}_{0.2} \mathrm{O}_{2}$ SPEs were shown to have a nearly Nernstian behavior at $25{ }^{\circ} \mathrm{C}$. All of these studies suggest that $\mathrm{CeO}_{2}$-based electrodes are of interest for monitoring $\mathrm{pH}$ over the widest temperature range.

\subsubsection{Repeatability and reproducibility}

Repeatability was verified by carrying out repeated analyses with the same sensor in $\mathrm{NH}_{4} \mathrm{Cl} / \mathrm{NH}_{3}$ buffer solutions ( $\mathrm{pH} 7.6$ and 8.6). Measurements were done for two hours at a rate of one reading per minute. RSD was $\leq 5 \%$ after 120 analyses, indicating that each type of SPE is reusable.

Reproducibility using different $\mathrm{CeO}_{2}$-based SPEs was determined by producing a series of $\mathrm{pH}$ calibration curves with 12 electrodes from two different plates on each of which six electrodes were printed. Calibration curves were based on 25 replicates (one reading per minute) in the $\mathrm{pH}$ scale ranging from 7.2 to 10.8 . Average sensitivity was $-(38 \pm 4) \mathrm{mV} / \mathrm{pH},-(40 \pm 4)$ $\mathrm{mV} / \mathrm{pH},-(51 \pm 2) \mathrm{mV} / \mathrm{pH}$ for $\mathrm{CeO}_{2^{-}}, \mathrm{Ce}_{0.8} \mathrm{Sm}_{0.2} \mathrm{O}_{2^{-}}$and $\mathrm{Ce}_{0.8} \mathrm{Zr}_{0.2} \mathrm{O}_{2}$-based SPEs, respectively. This is similar to the performance levels obtained for commonly used SPEs $[34,35,44]$ and shows the convenience of $\mathrm{CeO}_{2}$-based SPEs. Nevertheless, it is assumed that the measured potential results from a mixed potential Carbon/ $\mathrm{CeO}_{2}$-based oxide. Typical measurements done with $\mathrm{Ce}_{0.8} \mathrm{Zr}_{0.2} \mathrm{O}_{2}$-based SPE $\mathrm{pH}$ sensors (shown, for example, in figure 6: $\mathrm{E}^{\circ} \mathrm{Ce}_{0.8} \mathrm{Zr}_{0.2} \mathrm{O}_{2}$-based SPEs $\left.=(780 \pm 40) \mathrm{mV}\right)$ show the need for electrode calibration before any measurements are done on natural samples, like for all other sensors described in the 
literature. Work is now being done to develop reproducible $\mathrm{pH}$ screen-printed electrodes that can be used without preliminary calibration. $\mathrm{CeO}_{2}$-based oxide coated SPEs made by sputtering is foreseen.

\subsubsection{Storage stability}

The storage stability was studied by comparing the SPE analytical slopes in $\mathrm{NH}_{4} \mathrm{Cl} / \mathrm{NH}_{3}$ buffer solutions of freshly printed electrodes with those obtained with electrodes from the same batch that had been stored ten months at $25^{\circ} \mathrm{C}$ (i) in the ambient air and (ii) in a $\mathrm{N}_{2}$ inert glove-box. The conditions described above were used to compare the influence of carbon oxidation by atmospheric $\mathrm{O}_{2}(\mathrm{~g})$ and $\mathrm{H}_{2} \mathrm{O}(\mathrm{g})$.

Except for the unmodified carbon electrodes that were stored in the ambient air, for which the RSD on each measurement increased (from $5 \leq \mathrm{RSD}$ to $\mathrm{RSD} \leq 15 \%$ ), probably due to irreproducible carbon oxidation that led to the appearance of $\mathrm{pH}$-sensing $\mathrm{OH} / \mathrm{COOH}$ groups on the working surface, no significant difference in the $\mathrm{pH}$ potential slope was observed after the electrodes had been stored for 10 months. This (i) increases both the interest of and the stability of $\mathrm{CeO}_{2}$-based oxides and (ii) suggests that the electrodes stored in a vacuum (to minimize carbon oxidation that would increase carbon hydrophilic properties [50-52]) were well-suited to being integrated in an automated on-line analysis system for continuous monitoring without the need for maintenance over long periods.

\subsubsection{Hysteresis effect}

Solid oxide electrodes are subject to non-ideal effects such as hysteresis or memory effects that decrease the electrode accuracy and/or sustainability [3, 53, 54]. According to Bousse et al. (1990) [53], hysteresis or memory effects can be regarded as a delay of the voltage response versus $\mathrm{pH}$. 
Successive measurements were therefore taken using various devices for increasing and decreasing $\mathrm{pH}$ values in $\mathrm{NH}_{4} \mathrm{Cl} / \mathrm{NH}_{3}$ buffer solutions to study the hysteresis effect of the sensing devices. Experiments carried out two times with the same electrode in both directions, from $\mathrm{pH} 7.2$ to 10.8 , indicated that there was no hysteresis with regards to the sensitivity of $\mathrm{CeO}_{2}$-based SPEs (RSD $\leq 0.8 \%, \mathrm{n}=4$ slopes for each electrode), showing that this kind of sensors is of interest for continuous measurements.

\subsubsection{Influence of carbonate/hydrogenocarbonate buffer system and ionic strength}

The potential developed by oxide-based electrodes is mainly the result of the hydrogen ion but can be modified by the presence of some complexing ions and/or their concentrations [55]. The influence of the carbonate/hydrogenocarbonate buffer system on the analytical response of the $\mathrm{CeO}_{2}$-based SPEs was studied because carbonate system equilibria constrain the $\mathrm{pH}$ of the clay rock's pore-water [38]. Ionic strength was also investigated. Potentiometric measurements were done in $\mathrm{NaHCO}_{3} / \mathrm{Na}_{2} \mathrm{CO}_{3}$, at ionic strengths ranging from 0.05 to $0.2 \mathrm{~mol}$ $\mathrm{L}^{-1}$ (Fig. 7). The experiment consisted in taking one reading every $30 \mathrm{~s}$ in each sample for 30 minutes.

The voltage response of SPEs versus $\mathrm{pH}$ remains linear in spite of the presence of carbonate and hydrogenocarbonate ions. Sensitivities were similar to those obtained in $\mathrm{NH}_{4} \mathrm{Cl} / \mathrm{NH}_{3}$ buffer samples.

As regards the RSD based on reproducibility, neither ionic strength (in the range 0.05 to 0.2 mol ${ }^{-1}$ ) nor $\mathrm{HCO}_{3}{ }^{-} / \mathrm{CO}_{3}{ }^{2-}$ ions present in natural waters affects the sensitivity of $\mathrm{CeO}_{2}$-based SPEs, which suggests that they are of interest for $\mathrm{pH}$ measurements of the pore-water of the COx. 


\subsubsection{Calibration curves under atmospheric and anoxic conditions}

In addition to measurements done under atmospheric oxygen saturation (with $\mathrm{PO}_{2}$ about 0.2 atm) while the influence of the $\mathrm{O}_{2} / \mathrm{H}_{2} \mathrm{O}$ redox couple was being studied, several measurements were also done in a glove box $(\mathrm{GB})$ in an oxygen-free atmosphere $(100 \%$ nitrogen) at $25^{\circ} \mathrm{C}$.

These were done with reference to the anticipated decrease in the redox potential in the COx pore water caused by the decrease in the $\mathrm{O}_{2}$ concentration. Figure 8 shows the two calibration curves of the potential of the $\mathrm{Ce}_{0.8} \mathrm{Zr}_{0.2} \mathrm{O}_{2}$-based SPEs versus $\mathrm{pH}$ under atmospheric (atm) and anoxic (GB) conditions. Data include measurements taken in $\mathrm{NH}_{4} \mathrm{Cl} / \mathrm{NH}_{3}$ and $\mathrm{NaHCO}_{3} / \mathrm{Na}_{2} \mathrm{CO}_{3}$ buffer solutions. The same measurements were also done using a $10-\mathrm{mm}$ disk platinum electrode with a surface of $78.54 \mathrm{~mm}^{2}$ (data not shown).

The potential of the platinum electrode $\left(\mathrm{E}_{\mathrm{Pt}}\right)$ under atmospheric oxygen saturation is fixed by the $\mathrm{O}_{2} / \mathrm{H}_{2} \mathrm{O}$ redox couple. Under these conditions, $\mathrm{E}_{\mathrm{Pt}}$ is governed by the $\mathrm{PtO} / \mathrm{Pt}$ couple via $\mathrm{PtO}+2 \mathrm{H}^{+}+2 \mathrm{e}^{-} \Leftrightarrow \mathrm{Pt}+\mathrm{H}_{2} \mathrm{O}$ with $\mathrm{E}_{\mathrm{PtO} / \mathrm{Pt}}(\mathrm{mV})=60.5 \mathrm{pH}+902$, in agreement with Hoare (1968) [56] and Schuring et al. (1999) [57].

At the same $\mathrm{pH}$ and under aerobic conditions, a difference of about $120 \mathrm{mV}(\mathrm{pH} 0)$ is observed between $\mathrm{Pt}$ and $\mathrm{Ce}_{0.8} \mathrm{Zr}_{0.2} \mathrm{O}_{2}$-based SPEs. This is of the same order of magnitude (about $180 \mathrm{mV}$ ) as for anoxic conditions where $\mathrm{O}_{2} / \mathrm{H}_{2} \mathrm{O}$ is the predominant redox couple with a very low quantity of oxygen. Moreover, the slope of the potential-pH $\mathrm{Ce}_{0.8} \mathrm{Zr}_{0.2} \mathrm{O}_{2}$-based SPEs remains the same regardless of the medium $(51 \mathrm{mV})$, which is very important, while the intercept giving the potential at $\mathrm{pH}=0$ differs by about $110 \pm 6 \mathrm{mV}$.

This shows the dependence, although weak, of the $\mathrm{Ce}_{0.8} \mathrm{Zr}_{0.2} \mathrm{O}_{2}$-based SPE on the $\mathrm{O}_{2} / \mathrm{H}_{2} \mathrm{O}$ redox couple in the solution. This test provides information concerning the simultaneous but different behavior of two different electrodes under identical conditions and the same reference electrode. Knowledge of their electrochemical curves will allow us to draw 
potential-pH diagrams when observing and monitoring $\mathrm{pH}$ in the underground components of radioactive waste repositories where reference electrodes will not be used.

3.2.7 pH measurement applications: simulation of alkaline perturbation in the clay-rock porewater

Large quantities of cement and concrete will be used in the geological storage facilities for long-lived radioactive waste. An alkaline plume $(9 \leq \mathrm{pH} \leq 11)$ diffusing from old concrete through the pore-water of argillite-type rocks was simulated. The $\mathrm{pH}$ in $\mathrm{NaCl}\left(0.1 \mathrm{~mol} \mathrm{~L}^{-1}, \mathrm{pH}\right.$ $\approx 5.5)$ spiked with a $\mathrm{NaHCO}_{3} / \mathrm{Na}_{2} \mathrm{CO}_{3}$ buffer ( $\mathrm{pH} 10.5$, ionic strength 0.2$)(5.5 \leq \mathrm{pH} \leq 10.2)$ was continuously monitored using $\mathrm{CeO}_{2}$-based SPEs and classical glass membranes (Fig. 9). Experiments were done twice between $\mathrm{pH} \approx 5.5$ and $\approx 8.6$. The $\mathrm{pH}$ was then increased to 10.2. The samples containing $\mathrm{Ce}_{0.8} \mathrm{Zr}_{0.2} \mathrm{O}_{2}$-based SPEs were then spiked with $\mathrm{NaOH}(1 \mathrm{~mol} \mathrm{~L}$ ${ }^{1}$ ) in order to evaluate the electrode performance up to $\mathrm{pH} \geq 12$. One reading was recorded every $60 \mathrm{~s}$ for 36 hours.

The first experiments (between $\mathrm{pH} \approx 5.5$ and $\approx 8.6$ ) showed that the potential of the electrodes was somewhat affected by hysteresis. For a given potential E (mV/NHE), an uncertainty of 0.25 and $0.3 \mathrm{pH}$ units was observed for $\mathrm{CeO}_{2}$ as well as for $\mathrm{Ce}_{0.8} \mathrm{Zr}_{0.2} \mathrm{O}_{2}$-based SPEs and $\mathrm{Ce}_{0.8} \mathrm{Sm}_{0.2} \mathrm{O}_{2}$-based SPEs, respectively.

These results were obtained without prior conditioning of the sensors. Potential for $t=0$ was recorded immediately after immersing the dry electrodes in the sample solution. $\mathrm{CeO}_{2}$-based SPEs do not require pre-treatment, which is a great advantage if we consider that the simple, plastic devices can be used as disposable sensors. 
These results aimed to demonstrate the stability of $\mathrm{CeO}_{2}$-based SPEs for continuous $\mathrm{pH}$ recording. Although the $\mathrm{Ce}_{0.8} \mathrm{Sm}_{0.2} \mathrm{O}_{2}$-based SPEs were more sensitive than those obtained with a Sm stabilized ceria membrane [32], we can not yet claim that $\mathrm{Ce}_{0.8} \mathrm{Sm}_{0.2} \mathrm{O}_{2}$-based SPE oxides are better than $\mathrm{CeO}_{2}$-based SPEs for $\mathrm{pH}$ measurements at $25^{\circ} \mathrm{C}$. Of all the $\mathrm{CeO}_{2}$-based SPEs, $\mathrm{Ce}_{0.8} \mathrm{Zr}_{0.2} \mathrm{O}_{2}$ SPEs have a wide linear $\mathrm{pH}$ range (from 5.3 to 13.2, at least). They also exhibit almost ideal Nernstian response (sensitivity $-(51 \pm 3) \mathrm{mV} / \mathrm{pH}) \cdot \mathrm{Ce}_{0.8} \mathrm{Zr}_{0.2} \mathrm{O}_{2}$ SPEs appear, therefore, to be the electrodes best suited for accurate measurements. $\mathrm{CeO}_{2}$-based SPEs were shown to reach the performance levels of those previously described in the literature [14] and to be more robust for semi-continuous measurements in alkaline media [36, 37]. The reference electrode should be optimized for sustainability and robustness as was done with the sensors developed by Palchetti et al. (2000) [58] for field measurement of traceelements.

\section{Conclusions}

This study investigated the possible use of $\mathrm{CeO}_{2}$-based screen-printed electrodes $\left(\mathrm{CeO}_{2} \mathrm{SPEs}\right.$, $\mathrm{Ce}_{0.8} \mathrm{Sm}_{0.2} \mathrm{O}_{2}$ SPEs and $\mathrm{Ce}_{0.8} \mathrm{Zr}_{0.2} \mathrm{O}_{2} \mathrm{SPEs}$ ) for $\mathrm{pH}$ monitoring. The electrochemical behavior of $\mathrm{CeO}_{2}$-based SPEs showed that they could be used as electrochemical sensors without the need for high input impedance equipment. The results of potentiometric analysis demonstrated the feasibility of using this technology to measure $\mathrm{pH}$. $\mathrm{CeO}_{2}$-based SPEs showed a near-Nernstian behavior in the $\mathrm{pH}$ range of 6-11 and the response was somewhat affected by the direction of the $\mathrm{pH}$ change. These seem to be well-suited to monitoring the $\mathrm{pH}\left(\mathrm{T}=25^{\circ} \mathrm{C}\right)$ of the pore water in the $\mathrm{COx}$ formation during its evolution as a radioactive waste repository. $\mathrm{CeO}_{2}$-based SPEs were successfully used for continuous monitoring of $\mathrm{pH}$ for 100 hours.

Of the three types of electrodes studied, $\mathrm{Ce}_{0.8} \mathrm{Zr}_{0.2} \mathrm{O}_{2}$ SPEs appear to be the most suitable for accurate measurements on site, probably because $\mathrm{Ce}_{0.8} \mathrm{Zr}_{0.2} \mathrm{O}_{2}$ is the highest oxygen vacancy 
carrier. Vacuum-packed $\mathrm{Ce}_{0.8} \mathrm{Zr}_{0.2} \mathrm{O}_{2}$ SPEs could be integrated in automatic probes containing carrousels on which several electrodes would be stored in order to do continuous monitoring of $\mathrm{pH}$ without any maintenance over long periods by automatically changing the working electrode. More strongly designed probes using the same components could be considered for $\mathrm{pH}$ measurements in radioactive waste repositories.

\section{Acknowledgements}

This work was funded by i) a BRGM-ANDRA partnership (CAPTANDRA project 20092011, Dr. Stéphane Buschaert) and ii) the Cyprus Research Promotion Foundation for funding project KY-ГA/0907 NANOSENS (Cyprus-France Bilateral Collaboration). The authors would like to thank S. Gravani (University of Cyprus) for providing the powders.

\section{References}

[1] OECD NUCLEAR ENERGY AGENCY, Reversibility and Retrievability in Geologic Disposal of Radioactive Waste: Reflections at the International Level, OECD, Paris, 2001.

[2] S. Glab, A. Hulanicki, G. Edwall, F. Ingman, Crit. Rev. Anal. Chem. 21 (1989) 29.

[3] A. Fog, R.P. Buck, Sens. Actuators B 5 (1984) 137.

[4] M.J. Tarlov, S. Semancik, K.G. Kreider, Sens. Actuators B 1 (1990) 293.

[5] J.V. Dobson, P.R. Snodin, H.R. Thirsk, Electrochim. Acta 21 (1976) 527.

[6] T. Katsube, I. Lauks, J.N. Zemel, Sens. Actuators B 2 (1982) 399.

[7] L.D. Burke, J.K. Mulcahy, D.P. Whelan, J. Electroanal. Chem. 163 (1984) 117.

[8] P.J. Kinler, J.E. Heider, Sens. Actuators B 22 (1994) 13.

[9] F. Yue, T.S. Ngin, G. Hailin, Sens. Actuators B 32 (1996) 33.

[10] J. Hendrikse, W. Olthuis, P. Bergveld, Sens. Actuators B 53 (1998) 97.

[11] M. Wang, S. Yao, M. Madou, Sens. Actuators B 81 (2002) 313. 
[12] G.M. da Silva, S.G. Lemos, L.A. Pocrifka, P.D. Marreto, A.V. Rosario, E.C. Pereira, Anal. Chim. Acta 616 (2008) 36.

[13] K. Pasztor, A. Sekiguchi, N. Shimo, N. Kitamure, H. Masuhara, Sens. Actuators B 14 (1993) 561.

[14] R. Koncki, M. Mascini, Anal. Chim. Acta 351 (1997) 143.

[15] J.A. Mihell, J.K. Atkinson, Sens. Actuators B 48 (1998) 505.

[16] C. Colombo, T. Kappes, P.C. Hauser, Anal. Chim. Acta 412 (2000) 69.

[17] P. Shuk, K.V. Ramanujachary, M. Greenblatt, Electrochim. Acta 41 (1996) 2055.

[18] A. Eftekhari, Sens. Actuators B 88 (2003) 234.

[19] K. Arshak, E. Gill, A. Arshak, O. Korostynska, Sens. Actuators B 127 (2007) 42.

[20] H. Galster, pH Measurements-Fundamentals, Methods, Applications, Instrumentation, VCH, New York, 1991.

[21] C. Cachet-Vivier, B. Tribollet, V. Vivier, Talanta 82 (2010) 555.

[22] L.W. Niedrach, Science 207 (1980) 1200.

[23] L.W. Niedrach, J. Electrochem. Soc. 127 (1980) 2122.

[24] T. Tsuruta, D.D. Macdonald, J. Electrochem. Soc. 129 (1982) 1221.

[25] S. Hettiarachchi, D.D. Macdonald, J. Electrochem. Soc. 131 (1984) 2206.

[26] V.V. Kharton, F.M.B. Marques, A. Atkinson, Solid State Ionics 174 (2004) 135.

[27] Y. Inda, K. Yamashitaa, T. Umegaki, M. Greenblattb, Solid State Ionics 86-88 (1996) 1121.

[28] G.B. Balazs, R.S. Glass, Solid State Ionics 76 (1995) 155.

[29] K. Yamashita, K.V. Ramanujachary, M. Greenblatt, Solid State Ionics 81 (1995) 53.

[30] D.G. Brookins, Eh-pH diagrams for geochemistry, Springer-Verlag, New York, 1988.

[31] Y. Sugie, A. Mineshige, M. Kobune, S. Fujii, Thin Solid Films 250 (1994) 8.

[32] P. Shuk, K.V. Ramanujachary, M. Greenblatt, Solid State Ionics 85 (1996) 257. 
[33] K. Polychronopoulou, J.L.G. Fierro, A.M. Efstathiou, J. Catalysis 228 (2004) 417.

[34] S. Betelu, C. Vautrin-U1, J. Ly, A. Chaussé, Talanta 80 (2009) 372.

[35] C. Parat, S. Betelu, L. Authier, M. Potin-Gautier, Anal. Chim. Acta 573-574 (2006)

14.

[36] H.N. McMurray, P. Douglas, D. Abbot, Sens. Actuators B 28 (1995) 9.

[37] L. Qingwen, L. Guoan, S. Youqin, Anal. Chim. Acta 409 (2000) 137.

[38] E.C. Gaucher, C. Tournassat, F.J. Pearson, P. Blanc, C. Crouzet, C. Lerouge, S. Altmann, Geochim. et Cosmochim. Acta, 73 (2009) 6470.

[39] K. Polychronopoulou, C.N. Costa, A.M. Efstathiou, Appl. Catalysis A 272 (2004) 37.

[40] A. Cagnini, I. Palchetti, I. Lionti, M. Mascini, A.P.F. Turner Sens. Actuators B (1995) 24

85.

[41] J.E. Moneyron, A. de Roy, C. Forano, J.P. Besse, Appl. Clay Sci. 10 (1995) 163.

[42] O. Bagel, B. Limoges, B. Schollhorn, C. Degrand, Anal. Chem. 69 (1997) 4688.

[43] A.J. Bard, L. Faulkner, Electrochimie Principe, Méthodes et Applications, Masson, Paris, 1983.

[44] S. Betelu, C. Vautrin-Ul, A. Chaussé, Electrochem. Commun. 11 (2009) 383.

[45] D.D. Macdonald, S. Hettiarachchi, S.J. Lenhart, J. Solution Chem. 17 (1988) 719.

[46] L. Authier, B. Schöllhorn, B. Limoges, Electroanalysis 10 (1998) 1255.

[47] H. Iwahara, Solid State Ionics 77 (1995) 289.

[48] H. Iwahara, Solid State Ionics 86-88 (1996) 9.

[49] B.K. Narayanan, S.A. Akbar, P.K. Dutta, Sens. Actuators B 87 (2002) 480.

[50] R.C. Engstrom, V.A. Strasser, Anal. Chim. Acta 56 (1984) 136.

[51] J. Wang, P. Tuzhi, V. Villa, J. Electroanal. Chem. 234 (1987) 119.

[52] J. Wang, M. Pedrero, H. Sakslund, O. Hammerich, J. Pingarron, Analyst 121 (1996) 345. 
[53] L. Bousse, H.H. van den Vlekkert, N.F. de Rooij, Sens. Actuators B 2 (1990) 103.

[54] Y.H. Liao, J.C. Chou, Sens. Actuators B 128 (2008) 603.

[55] C.R. Caflisch, L.R. Pucacco, N.W. Carter, Kidney Int. 14 (1978) 126.

[56] J.P. Hoare, The electrochemistry of oxygen. Interscience Publication, New York, 1968 p.19.

[57] J. Schüring, H.D. Schulz, W.R. Fischer, Redox: Fundamentals, Processes and Applications, Springer-Verlag ed., Berlin, Heidelberg, New York, London, Paris, Tokyo, Hong Kong, Barcelona, Budapest, 1999.

[58] I. Palchetti, S. Laschi, M. Mascini, Anal. Chim. Acta 530 (2005) 61. 